\title{
Evidence for Involvement of TRPV1 Receptors and Potassium Channels in the Seizures Induced by $\alpha$-Sanshool
}

\section{두)(1) $(8)$}

\author{
Authors \\ Benito Reyes-Trejo', Mario Noel Morales-Hernández¹, Gloria Melisa González-Anduaga², José Luis Balderas-López², \\ José Carlos Tavares-Carvalho ${ }^{3}$, Andrés Navarrete ${ }^{2}$
}

\section{Affiliations}

1 Agricultural High School Department, Natural Products Laboratory, Chemistry Area, Autonomous University Chapingo, Chapingo, Mexico

2 Faculty of Chemistry, Department of Pharmacy, National Autonomous University of Mexico, University City,

Coyoacan 04510, Mexico City, Mexico

3 Department of Biological Sciences and Health, Laboratory of Pharmaceutical Research, Pharmacy Course, Federal University of Amapa, Macapa, AP, Brazil

Key words

Zanthoxylum liebmannianum (Rutaceae), seizures, TRPV1, potassium channels, isobutylamides

$\begin{array}{ll}\text { received } & 27.09 .2018 \\ \text { revised } & 28.02 .2019 \\ \text { accepted } & 01.03 .2019\end{array}$

Bibliography

DOI https://doi.org/10.1055/a-0871-2496

Planta Med Int Open 2019; 6: 1-5

(C) Georg Thieme Verlag KG Stuttgart · New York

ISSN 2509-9264

\section{Correspondence}

Dr. Andrés Navarrete

Facultad de Química,

Departamento de Farmacia

Universidad Nacional Autónoma de México

Ciudad Universitaria Coyoacán 04510

Ciudad de México

México

Tel.: + 52/55/56225291, Fax: + 52/55/56225 329

anavarrt@unam.mx

Supporting Information for this article is available online at http://www.thieme-connect.de/products.

\section{ABSTRACT}

$\alpha$-Sanshool is an alkamide isolated from the stem bark of Zanthoxylum liebmannianum, a Mexican medicinal plant known as Colopahtle. Our research group has reported that the intraperitoneal administration of $\alpha$-sanshool induces tonic-clonic seizures in mice. In the present study, we investigated the convulsive effect of this alkamide and elucidated its mechanism of action by comparing with well-known convulsive and anticonvulsive drugs in an in vivo approach. $\alpha$-Sanshool showed a potent $\left(\mathrm{ED}_{50}[\mathrm{CL} 95 \%]=3.06[2.92-3.22] \mathrm{mg} / \mathrm{kg}\right)$ and immediate $(2 \pm 2 \mathrm{~s})$ seizure effect after the intraperitoneal administration in mice. The convulsive effect of this alkamide was only observed for intraperitoneal administration; the oral route did not show any effect. $\alpha$-Sanshool was less potent than strychnine $\left(\mathrm{ED}_{50}[\mathrm{CL} 95 \%]=1.53[1.44-1.62] \mathrm{mg} / \mathrm{kg}\right)$, but more effective than bicuculline, 4-aminopyridine, affinin, and pentylenetetrazol, in that order. The seizures induced by $\alpha$-sanshool were reduced by capsazepine and diazoxide, suggesting the involvement of TRPV1 and potassium channels in the mechanism of action of this compound. 


\section{ABBREVIATIONS}

CNS central nervous system

GC/MS gas chromatography coupled to mass spectrometry

ICR Institute of Cancer research

$\mathrm{K}_{2 \mathrm{P}} \quad$ 2-pore domain potassium channels

$\mathrm{K}_{\text {ATP }} \quad$ ATP-dependent potassium channels

TRPV1 transient receptor potential vanilloid type 1

TRPA1 transient receptor potential ankyrin type 1

\section{Introduction}

Alkamides are common constituents in plants of the Echinaceaeae, Zanthoxylum, Capsicum, Piperaceae, Spilanthes, Acmella, and Heliopsis genera [1]. Several plants of the genus Zanthoxylum (Rutaceae) are used in the traditional medicine of native cultures from Africa, America, and Asia [2]. These compounds have a diversity of biological activities, including insecticidal, antibacterial, antifungal, antiparasitic, analgesic, and local anesthetic [3-5]. In the Brazilian Amazon region, Acmella oleracea (L.) R.K. Jansen, which contains alkamides, has been reported as an aphrodisiac [6]. Also, some alkamides and the plants that provide them are used as flavoring in foods and beverages due to the unique tingling and numbing orosensations that they produce. For example, the Brazilian alcoholic beverage Cachaça de Jambu contains an extract of $A$. oleracea, in which the alkamide spilanthol is a major metabolite [6]. In recent years, the academic and industrial interest for alkamides has remarkably increased, both for their medical and cosmetic applications and because of their biological mechanisms of action [3]. Sanshools are the predominant alkamides in the Zanthoxylum genus [3]. The stimulation of transient receptor potential ankyrin 1 (TRPA1) and TRP vanilloid 1 (TRPV1) channels, the blockage of 2-pore domain potassium channels KCNK3 (TASK-1), KCNK9 (TASK-3) and KCNK18 (TRESK), as well as the antagonism of the cannabinoid receptors 1 (CB1) and 2 (CB2) and the agonist effect on $C B 2$, have been suggested as biomolecular targets for these compounds [3]. In a previous study, we reported the isolation of $\alpha$-sanshool ( $>$ Fig. 1) from the stem bark of Zanthoxylum liebmannianum (Engelm.) P.Wilson (Rutaceae) and its anthelmintic effect in naturally infected sheep [4]. In that work, we also noticed that the intraperitoneal injection of this compound induced tonic-clonic seizures in mice. Although low toxicity is generally associated with natural and synthetic alkamides, their convulsive effect in mice was recently reported [7]. This is of great significance due to the growing medical and cosmetic interest in plant extracts containing these compounds, even though little is known about their toxic effects. Accordingly, we were interested in knowing the convulsive potency of $\alpha$-sanshool, a natural alkamide. In this work, we compared the seizures induced by $\alpha$-sanshool with those caused by 4 known convulsive drugs: bicuculline (GABA antagonist), 4-aminopyridine (voltage-activated potassium channels KCND2/KCND3 blocker), strychnine (glycine antagonist) and pentylenetetrazol (GABAergic blocker), and also with the effect of affinin (spilanthol), isolated from Heliopsis longipes (A. Gray) S.F. Blake (Asteraceae) roots. We also investigated the inhibition of the $\alpha$-sanshool-induced seizures by diazepam and pentobarbital (positive allosteric modulators of $\mathrm{GABA}_{A}$ receptors), diazoxide (ATP-sensitive potassium channels acti- vator), ethosuximide (low-threshold T-type $\mathrm{Ca}^{2+}$ channels blocker), capsazepine (TRPV1 antagonist), and carbamazepine (voltage-gated sodium channels blocker).

\section{Results}

- Fig. 2 shows the dose-response curves for seizures induced by the intraperitoneal administration of increasing doses of the convulsive drugs affinin and $\alpha$-sanshool. As seen in the plots, the seizure incidence increased with increasing dosage. $\alpha$-Sanshool was less effective than strychnine ( $\triangleright$ Table 1 ) but more potent than bicuculline, 4-aminopyridine, affinin, and pentylenetetrazol, in that

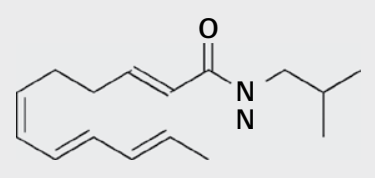

Fig. 1 Structure of $\alpha$-sanshool.

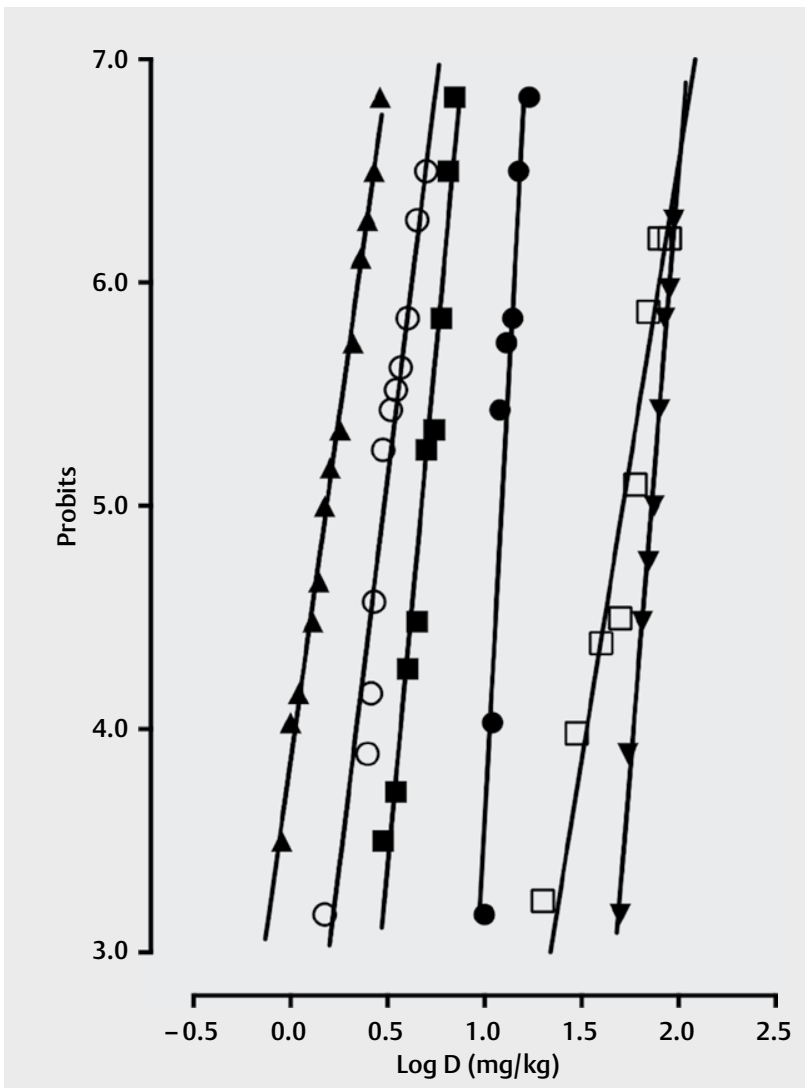

- Fig. 2 Dose response curves for seizures induced by the intraperitoneal administration of $\alpha$-sanshool ( $(0)$, strychnine ( $\mathbf{\Delta})$, bicuculline $(\square)$, 4-aminopyridine $(\bullet)$, affinin $(\square)$, and pentylenetetrazol $(\boldsymbol{\nabla})$. The graph represents the decimal logarithm of the doses used for each drug vs. probit. Each symbol represents the probit, derivate from the cumulative frequency of animals that present seizures/total of animals (30) for each dose. 
order. The latency to the first seizure induced by this alkamide was extremely short, only 2 s ( $\triangleright$ Table 1 ), with a mortality of $100 \%$. Contrastingly, the oral administration of $\alpha$-sanshool at the same doses than those used for the intraperitoneal injections did not induce seizures. The seizure incidence and the mortality induced by $\alpha$-sanshool at $9 \mathrm{mg} / \mathrm{kg}$ were reduced by $84 \%$ when administering capsazepine $(50 \mathrm{mg} / \mathrm{kg}$, s.c.). Diazoxide reduced them by $44 \%$ (at $10 \mathrm{mg} / \mathrm{kg}$, i.p.) and $50 \%$ (at $100 \mathrm{mg} / \mathrm{kg}$, i.p.). Diazepam and pentobarbital were effective (66\% reduction) only at very high doses. Carbamazepine and ethosuximide did not inhibit the $\alpha$-sanshoolinduced seizures ( $\triangleright$ Table 2 ).

\section{Discussion}

$\alpha$-Sanshool, a compound found in the stem bark of Z. liebmannianum $[4,8]$, showed potent and immediate tonic-clonic seizures in mice. This effect was partially inhibited by capsazepine, diazoxide and high doses of diazepam and pentobarbital ( $>$ Table 2 ). The powerful $\left(\mathrm{ED}_{50}=3 \mathrm{mg} / \mathrm{kg}\right)$ and immediate $(2 \mathrm{~s})$ seizure-inducing effect showed by this compound differs from the pattern of the other convulsive drugs tested ( $\vee$ Table 1 ). This effect, first observed for $\alpha$-sanshool [3,4], may be a pharmacological property of alkamides in general when they are intraperitoneally administered. This is consistent with a recent report for affinin $(90 \mathrm{mg} / \mathrm{kg}$, i.p.), capsaicin $(90 \mathrm{mg} / \mathrm{kg}$, i.p.) and the synthetic alkamide $\mathrm{N}$-isobutyl-dihydroferuloylamide ( $180 \mathrm{mg} / \mathrm{kg}$, i.p.) in mice [7]. In that work, the authors found that affinin did not induce seizures at doses lower than $90 \mathrm{mg} / \mathrm{kg}$ (i.p.), though we observed its convulsive effect from $20-100 \mathrm{mg} / \mathrm{kg}$ in mice $\left(E D_{50}=51.74 \mathrm{mg} / \mathrm{kg}\right.$, i.p., > Fig. 2). It is worth noting that the oral administration of $\alpha$-sanshool did not induce seizures, suggesting either its poor absorption or fast metabolism. However, in a pilot pharmacokinetic study in humans, 2 alkamides with a structure similar to that of $\alpha$-sanshool (hydroxy- $\alpha$ sanshool and hydroxy- $\beta$-sanshool) were absorbed after the oral administration of an extract Zanthoxylum spp. fruits, but the rate of absorption for these compounds was not reported [9]. Therefore, additional studies are required to explain the absence of seizure effects in mice when $\alpha$-sanshool is orally administered.

The seizures and mortality induced by $\alpha$-sanshool were reduced to only $16 \%$ by the TRPV 1 antagonist capsazepine at $50 \mathrm{mg} / \mathrm{kg}$ (s.c.) ( $\triangleright$ Table 2). In an additional experiment, the seizures induced by affinin at $80 \mathrm{mg} / \mathrm{kg}$ were completely inhibited by capsazepine $(50 \mathrm{mg} / \mathrm{kg}$, s.c.). TRPV1 channels, which are considered partially responsible for epileptic seizures and peripheral pain [10], have

- Table 1 Median effective doses 50 (MD50, mg/kg) and 95\% confidence limit $(C L)$ for the evaluated convulsive drugs.

\begin{tabular}{|l|c|c|c|}
\hline Drug & ED50 (mg/kg) & CL 95\% & $\begin{array}{c}\text { Latency of } \\
\text { onset (s) }\end{array}$ \\
\hline Strychnine & 1.53 & $1.44-1.62$ & $184 \pm 32$ \\
\hline$\alpha$-Sanshool & 3.06 & $2.92-3.22$ & $2 \pm 2$ \\
\hline Bicuculline & 4.78 & $4.55-5.03$ & $76 \pm 6$ \\
\hline 4-Aminopyridine & 12.10 & $11.63-12.50$ & $364 \pm 34$ \\
\hline Affinin & 51.74 & $47.07-56.33$ & $332 \pm 12$ \\
\hline Pentylenetetrazol & 73.61 & $70.94-76.37$ & $82 \pm 11$ \\
\hline
\end{tabular}

been suggested as a biomolecular target for alkamides [3]. Therefore, the partial inhibition of the $\alpha$-sanshool-induced convulsions by the TRPV1-antagonist capsazepine suggests that this alkamide induces the seizures, at least in part, by stimulating the TRPV1 channels ( $\triangleright$ Table 2 ). It is possible that convulsions induced by affinin, capsaicin, and the synthetic alkamide reported by de la Rosa et al. [7] also occur via the same mechanism. Additional experimental data are required to assess this statement.

$\mathrm{K}_{2 \mathrm{P}}$ channels have also been suggested as molecular targets for alkamides [3]. These channels are widely expressed in the central and peripheral nervous system, and their blockage has been associated with local anesthetic-induced seizures [11]. In a previous work, it was reported that the convulsions induced by the local anesthetic bupivacaine $\left(50 \mathrm{mg} / \mathrm{kg}\right.$, i.p.), a blocker of $\mathrm{K}_{2 \mathrm{P}}$ channels, were reduced by intraperitoneal administration of diazoxide (10 and $100 \mathrm{mg} / \mathrm{kg}$ ), which activates $\mathrm{K}_{\text {ATP }}$ channels [12]. Here, we found that diazoxide reduced the $\alpha$-sanshool induced seizures ( $\triangleright$ Table 2 ) at the same doses than those used to reduce the bupivacaine-induced seizures [12]. Furthermore, seizures induced by 4 -aminopyridine, a blocker of voltage-activated potassium channels KCND2/KCND3, were suppressed by capsazepine [13]. Therefore, a cross-effect between the 2-pore domain $\left(\mathrm{K}_{2 \mathrm{P}}\right)$ and voltage-activated potassium channels may be possible. These findings suggest that seizures-induced by $\alpha$-sanshool result from a decrease $\mathrm{K}^{+}$efflux from nervous tissue.

Moreover, the doses of diazepam and pentobarbital required to reduce the seizures induced by $\alpha$-sanshool were very high ( $\triangleright$ Table 2 ), and the immediate convulsive effect imply a peripheral effect rather than a central one. These results indicate that $\alpha$-sanshool did not act on the $\mathrm{GABA}_{A}$ receptor. Contrastingly, the participation of $\mathrm{GABA}_{A}$ receptors has been suggested in the antinociceptive effect of the alkamide affinin [14]. Also, it has been reported that $G_{A B A_{A}}$ receptors are involved in the ototoxicity of local anesthetics because of the efficacy of benzodiazepines when treating central tinnitus, in which $\mathrm{K}_{2 \mathrm{P}}$ channels are implicated [15]. An association between $\mathrm{GABA}_{A}$ receptors and

- Table 2 Effect of several anticonvulsant drugs and diazoxide on the seizures induced by intraperitoneal administration of $\alpha$-sanshool at $9 \mathrm{mg} / \mathrm{kg}$.

\begin{tabular}{|c|c|c|c|c|c|}
\hline \multirow[t]{2}{*}{ Drug } & \multirow{2}{*}{$\begin{array}{l}\text { Dose } \\
(\mathrm{mg} / \mathrm{kg})\end{array}$} & \multirow[t]{2}{*}{$\mathbf{N}$} & \multicolumn{2}{|l|}{ Seizures } & \multirow{2}{*}{$\begin{array}{l}\text { Mortality } \\
\text { (\%) }\end{array}$} \\
\hline & & & $\begin{array}{l}\text { Response/ } \\
\text { total }\end{array}$ & Percent & \\
\hline \multirow[t]{5}{*}{ Diazepam } & 2.0 & 6 & $6 / 6$ & 100 & 100 \\
\hline & 2.5 & 6 & $6 / 6$ & 100 & 100 \\
\hline & 5.0 & 6 & $6 / 6$ & 100 & 100 \\
\hline & 8.5 & 6 & $6 / 6$ & 100 & 100 \\
\hline & 10.0 & 6 & $2 / 6$ & 33 & 33 \\
\hline \multirow[t]{2}{*}{ Pentobarbital } & 42.0 & 6 & $6 / 6$ & 100 & 100 \\
\hline & 63.0 & 6 & $2 / 6$ & 33 & 33 \\
\hline \multirow[t]{2}{*}{ Diazoxide } & 10.0 & 6 & $4 / 6$ & 66 & 66 \\
\hline & 100.0 & 6 & $3 / 6$ & 50 & 50 \\
\hline Capsazepine & 50.0 & 6 & $1 / 6$ & 16 & 16 \\
\hline \multirow{2}{*}{$\begin{array}{l}\text { Carbamaz- } \\
\text { epine }\end{array}$} & 100.0 & 6 & $6 / 6$ & 100 & 100 \\
\hline & 200.0 & 6 & $6 / 6$ & 100 & 100 \\
\hline Ethosuximide & 150.0 & 6 & $6 / 6$ & 100 & 100 \\
\hline
\end{tabular}


the alkamides acting on potassium channels is likely. However, further experimental support is needed to establish this association.

Based on the above, $\alpha$-sanshool and other natural or synthetic alkamides can be a useful pharmacological tool to study the seizures induced by the stimulation of TRPV1 or by the blockage $\mathrm{K}_{2 \mathrm{P}}$ and $\mathrm{K}_{\text {ATP }}$ channels.

In conclusion, we found that intraperitoneally administered $\alpha$-sanshool induces seizures with high potency $\left(E_{50}=3 \mathrm{mg} / \mathrm{kg}\right)$ and an extremely short latency ( $2 \mathrm{~s})$. These seizures are reduced by capsazepine and diazoxide, suggesting the involvement of TRPV1 and potassium channels in the convulsant mechanism of this alkamide. Rather than an effect on the CNS, the drug may have a peripheral effect on nervous tissue.

${ }^{1} \mathrm{H}$-NMR and GC/MS spectra of $\alpha$-sanshool, and affinin are available as Supporting Information.

\section{Materials and Methods}

\section{General}

${ }^{1} \mathrm{H}-\mathrm{NMR}(400 \mathrm{MHz})$ and ${ }^{13} \mathrm{C}-\mathrm{NMR}(100 \mathrm{MHz})$ spectra were registered on a Varian VNMRS 400 spectrometer in $\mathrm{CDCl}_{3}$ with tetramethylsilane as internal standard. GC/MS was performed using an Agilent chromatograph (6890N, Agilent Technologies) equipped with a time-of-flight mass spectrometric detector (LECO) under the following conditions: DB-5MS capillary column $(20 \mathrm{~m} \times 0.18 \mathrm{~mm}$, film thickness $0.18 \mu \mathrm{m})$; He as carrier gas ( $1 \mathrm{~mL} / \mathrm{min}$ flow rate), injection in split mode (1:400); injector at $300^{\circ} \mathrm{C}$. For the MS, the conditions were as follows: electron impact ionization voltage, 70 $\mathrm{eV}$; ion temperature source, $200^{\circ} \mathrm{C}$; mass scan mode, $20 \mathrm{scan} / \mathrm{s}$; mass range, $45-550 \mathrm{~m} / \mathrm{z}$.

\section{Plant material}

Dried roots of $H$. longipes were kindly provided by Laboratorios Mixim S.A. de C.V. (Mexico City, Mexico). They were harvested from Mixim's growing fields in July 2015 (Batch number 6702). A voucher specimen (number 2015011) was deposited at the herbarium of the Universidad Autónoma Chapingo, Mexico. The stem bark of Z. liebmannianum was collected at Valle de Tehuacán, Puebla, Mexico, in October 2015. A voucher specimen (number 2015126) was also deposited at the herbarium.

\section{Extraction and isolation}

Isolation of affinin

Dried roots of $H$. longipes (1012g) were ground and extracted with a mixture of dichloromethane-acetone $(9: 1 \mathrm{v} / \mathrm{v})$ in a Soxhlet apparatus for $4 \mathrm{~h}$. The extract was filtered through Whatman paper (No. 2) and the solvent evaporated in a rotatory evaporator under reduced pressure at $40^{\circ} \mathrm{C}$. The solvent-free extract was a dark-yellow semisolid $(19.3 \mathrm{~g}, 1.91 \%)$ and was stored at $4{ }^{\circ} \mathrm{C}$ under nitrogen. Batches of $2 \mathrm{~g}$ each were fractionated by open column chromatography using silica gel ( $40 \mathrm{~g}$, Kiesegel 60 Merck 100-230 mesh, normal phase, $2 \times 100 \mathrm{~cm})$, using hexane:ethyl acetate as eluent (9:1, 8:2, $7: 3$, and $4: 6)$. Sixty fractions of $10 \mathrm{~mL}$ each were collected. The fractions eluted with the 8:2 system was analyzed by TLC; after spraying with acidic anisaldehyde $(0.5 \mathrm{~mL}$ of anisaldehyde in $50 \mathrm{~mL}$ gla- cial acid and $1 \mathrm{~mL} 97 \%$ sulfuric acid), the same purple spot was observed for all of them ( $R f=0.3$, hexane: ethyl acetate $6: 4)$. These fractions (700 mg, yellow oil) were then subjected to a second chromatographic column (10 g, Kiesegel 60 Merck 100-230 mesh, normal phase, $1 \times 100 \mathrm{~cm}$ ) using hexane:ethyl acetate (9:1). An apparently pure yellow oil $(320 \mathrm{mg}$ ) was obtained; it had the same Rf than an authentic affinin sample, which was kindly provided by Dr. José Fausto Rivero (Facultad de Química UNAM). The identity of affinin was stablished by comparing the experimental NMR spectroscopic constants with those reported in the literature $[8,16]$. The purity of affinin (97\%) was determined by GC/MS.

\section{Isolation of $\alpha$-sanshool}

Air dried Z. liebmannianum stem bark $(2 \mathrm{~kg})$ was ground to a fine powder and subjected to extraction by maceration at room temperature $\left(22 \pm 2{ }^{\circ} \mathrm{C}\right)$ with either hexane or dichloromethane for $3 \mathrm{~d}$ in a 1:4 ratio $(\mathrm{w} / \mathrm{v})$. The extracts were filtered, and the solvents evaporated under reduced pressure at $40^{\circ} \mathrm{C}$, yielding 58 (hexane) and 141 (dichloromethane) g of syrupy residues. Part of the dichloromethane extract $(31 \mathrm{~g})$ was further fractionated by open column chromatography (300 g, Kiesegel 60 Merck 100-230 mesh, normal phase, $5 \times 100 \mathrm{~cm})$ using dichloromethane:ethyl acetate $(9: 1,8: 2$ and $1: 1)$. Eighty fractions of $100 \mathrm{~mL}$ each were collected. Fractions 29-46 (4g) eluted with the 9:1 system were pooled and re-chromatographed $(40 \mathrm{~g}$, Kiesegel 60 Merck 100-230 mesh, normal phase, $2 \times 100 \mathrm{~cm}$ ) with dichloromethane:ethyl acetate 9:2. Ninety fractions of $20 \mathrm{~mL}$ each were collected. From fractions 14 to 65 , a yellow oil $(635 \mathrm{mg}, 0.14 \%)$ was obtained. This oil was identified as $\alpha$-sanshool by comparison of the NMR spectral data with those reported for this amide [17]. The purity of $\alpha$-sanshool (94\%) was stablished by GC/MS.

\section{Animals}

All the experiments were performed on adult male ICR mice weighing 25-34 g (60 d old), purchased from Centro UNAM-Harlan (Harlan México, S.A. de C.V.). Procedures involving animals and their care were conducted in conformity with the Mexican Official Norm for Animal Care and Handling (NOM-062-ZOO-1999) and in compliance with international rules on care and use of laboratory animals. Furthermore, clearance for conducting the studies was obtained from the Ethics Committee for the Use of Animals in Pharmacological and Toxicological Testing (CICUAL/126/16, January 2016), Facultad de Química, UNAM. During the development of the experiments, the animals had free access to water and food, with a $12 \mathrm{~h}$ light-dark cycle at room temperature $\left(22 \pm 2{ }^{\circ} \mathrm{C}\right)$. Experiments were carried out between 9:00 and 15:00.

\section{Drugs}

Pentylenetetrazol (P6500, $\geq 99 \%$ ), strychnine (S0532, $\geq 98 \%)$, 4-aminopyridine ( $275875, \geq 99 \%$ ), ethosuximide (E7138, $\geq 98 \%$ ), and diazoxide (D9035, minimum 98\%) were dissolved in saline solution (0.9\%). Bicuculline $(14340, \geq 97 \%)$ was dissolved in phosphate buffered saline solution ( $\mathrm{pH}=7.5$ ), carbamazepine ( $\mathrm{C} 4024, \geq 98 \%$ ) in propylene glycol (10\% in saline solution), and capsazepine (C191, $\geq 98 \%$ ) in DMSO (10\% in saline solution). All the drugs were purchased from Sigma Aldrich. A pharmaceutical solution of sodi- 
um pentobarbital (Anestesal) for veterinary use was purchased from Pfizer S.A. de C.V. (México). Diazepam (Roche S.A.) and affinin ( $97 \%$ by GC/MS), isolated from $H$. longipes roots, were suspended in $0.5 \%$ Tween 80 in saline solution. $\alpha$-Sanshool ( $94 \%$ by GC/MS), obtained from the stem bark of Z. liebmannianum, was dissolved in DMSO (10\% in saline solution). The drugs were freshly prepared each time and intraperitoneally injected in a volume of $0.1 \mathrm{~mL} / 10 \mathrm{~g}$ body weight.

\section{Convulsive effect}

As a measure of the central nervous system toxicity, we quantified the effect of increasing doses of the drugs on the induction and latency of onset of seizures in individual male ICR mice ( $n=30$ each). The dosage was chosen based on preliminary data to cover a range that encompassed doses that caused no observable seizure to those that consistently evoked seizures: $\alpha$-sanshool $1.5-9.0 \mathrm{mg} / \mathrm{kg}$, at $0.5 \mathrm{mg} / \mathrm{kg}$ intervals, pentylenetetrazol $55-100 \mathrm{mg} / \mathrm{kg}$, at $5 \mathrm{mg} / \mathrm{kg}$ intervals, strychnine $0.9-3.0 \mathrm{mg} / \mathrm{kg}$, at $0.1 \mathrm{mg} / \mathrm{kg}$ intervals, 4 -aminopyridine $10-18 \mathrm{mg} / \mathrm{kg}$, at $1.0 \mathrm{mg} / \mathrm{kg}$ intervals, affinin $20-$ $100 \mathrm{mg} / \mathrm{kg}$, at $10 \mathrm{mg} / \mathrm{kg}$ intervals, and bicuculline $3.0-7.5 \mathrm{mg} / \mathrm{kg}$, at $0.5 \mathrm{mg} / \mathrm{kg}$ intervals. Increasing doses of each drug were injected intraperitoneally; in some cases, mice received only a single dose. The incidence of tonic-clonic seizures and latency at first seizure were recorded. Seizure signs were characterized by whole-body jumps or bursts of running motions (clonic seizure) and rigidity with forelimbs and hindlimbs caudally extended (tonic seizure). A series of quantal dose-response curves were fitted and statistically analyzed using probit analysis [18]. In addition, the ability to inhibit the $\alpha$-sanshool-induced seizures was determined for the following drugs: diazepam $(2.5,5,8.5$, and $10 \mathrm{mg} / \mathrm{kg}$, i.p.) and pentobarbital (42 and $63 \mathrm{mg} / \mathrm{kg}$, i.p.) doses experimentally determined; carbamazepine (100 and $200 \mathrm{mg} / \mathrm{kg}$, i.p.), ethosuximide $(150 \mathrm{mg} / \mathrm{kg}$, i.p.), and capsazepine ( $50 \mathrm{mg} / \mathrm{kg}$, s.c.) doses based on the work by González-Reyes et al. [13]; and diazoxide (10 and $100 \mathrm{mg} / \mathrm{kg}$, i.p.) doses based on the work by Gantenbein et al. [12]. The drugs were administered $30 \mathrm{~min}$ before $\alpha$-sanshool $(9 \mathrm{mg} / \mathrm{kg}$, i.p.) in groups of 6 animals each.

\section{Supporting Information}

$\mathrm{H}$-NMR and GC/MS spectra of $\alpha$-sanshool, and affinin are available as Supporting Information.

\section{Acknowledgments}

This work was supported by grants PAIP5000-9143 from Facultad de Química and PAPIIT-IN216516 from Dirección General de Asuntos del Personal Académico (DGAPA), Universidad Nacional Autónoma de México (UNAM).

\section{Conflict of Interest}

The authors have no conflicts of interest to declare.

\section{References}

[1] Boonen J, Baert B, Burvenich C, Blondeel P, De Saeger S, De Spiegeleer B. LC-MS profiling of $\mathrm{N}$-alkylamides in Spilanthes acmella extract and the transmucosal behaviour of its main bio-active spilanthol. J Pharm Biomed Anal 2010; 53: 243-249

[2] You Y, Zhou M, Lu H, Shirima GG, Cheng Y, Liu X. Sanshool from Zanthoxylum $L$. induces apoptosis in human hepatocarcinoma HepG2 cells. Food Sci Biotechnol 2015; 24: 2169-2175

[3] Chruma J], Cullen D], Bowman L, Toy PH. Polyunsaturated fatty acid amides from the Zanthoxylum genus - from culinary curiosities to probes for chemical biology. Nat Prod Rep 2018; 0: 1-21

[4] Navarrete A, Hong E. Anthelmintic properties of alpha-sanshool from Zanthoxylum liebmannianum. Planta Med 1996; 62: 250-251

[5] Arrieta J, Reyes B, Calzada F, Cedillo-Rivera R, Navarrete A. Amoebicidal and giardicidal compounds from the leaves of Zanthoxylum liebmannianum. Fitoterapia 2001; 72: 295-267

[6] da Rocha CF, de Medeiros Souza Lima Y, Carvalho HO, Pinto RC, Ferreira IM, Castro AN, Lima CS, Carvalho JCT. Action of the hydroethanolic extract of the flowers of Acmella oleracea (L.) R.K. Jansen on the reproductive performance of Wistar females rats: a popular female aphrodisiac from the Amazon. J Ethnopharmacol 2018; 214: 301-308

[7] de la Rosa-Lugo V, Acevedo-Quiroz M, Déciga-Campos M, Rios MY. Antinociceptive effect of natural and synthetic alkamides involves TRPV1 receptors. J Pharm Pharmacol 2017; 69: 884-895

[8] Castro-Ruiz J, Rojas-Molina A, Luna-Vázquez F, Rivero-Cruz F, García-Gasca T, Ibarra-Alvarado C. Affinin (spilanthol), isolated from Heliopsis longipes, induces vasodilation via activation of gasotransmitters and prostacyclin signaling pathways. Int J Mol Sci 2017; 18: 218

[9] Munekage M, Kitagawa H, Ichikawa K, Watanabe J, Aoki K, Kono T, Hanazaki K. Pharmacokinetics of Daikenchuto, a traditional Japanese medicine (Kampo) after single oral administration to healthy Japanese volunteers. Drug Metab Dispos 2011; 39: 1784-1788

[10] Nazıroğlu M. TRPV1 channel: A potential drug target for treating epilepsy. Curr Neuropharmacol 2015; 13: 239-247

[11] Kindler C, Yost C. Two-pore domain potassium channels: new sites of local anesthetic action and toxicity. Reg Anesth Pain Med 2005; 30: 260-274

[12] Gantenbein M, Attolini L, Bruguerolle B. Effect of four potassium channel agonists on bupivacaine-induced toxicity in mice. Life Sci 1995; 57: PL113-PL116

[13] Gonzalez-Reyes LE, Ladas TP, Chiang CC, Durand DM. TRPV1 antagonist capsazepine suppresses 4-AP-induced epileptiform activity in vitro and electrographic seizures in vivo. Exp Neurol 2013; 250: 321-332

[14] Déciga-Campos M, Rios M, Aguilar-Guadarrama A. Antinociceptive effect of Heliopsis longipes extract and affinin in mice. Planta Med 2010; 76: 665-670

[15] Kanjhan R, Balke CL, Housley GD, Bellingham MC, Noakes PG. Developmental expression of two-pore domain $\mathrm{K}+$ channels, TASK-1 and TREK-1, in the rat cochlea. Neuroreport 2004; 15: 437-441

[16] López-Martínez S, Aguilar-Guadarrama AB, Rios MY. Minor alkamides from Heliopsis longipes S.F. Blake (Asteraceae) fresh roots. Phytochem Lett 2011; 4: 275-279

[17] Navarrete A, Flores A, Sixtos C. Análisis isobolográfico de la interacción entre $\alpha$-sanshool, sesamina, asarinina, fagaramida y piperina sobre la actividad larvicida en Culex quinquefasciatus Say. Rev la Soc Quim México 2003; 47: 178-185

[18] Tallarida RJ. Drug synergism and dose-effect data analysis. New York: Chapman and Hall/CRC 2000; 